\title{
The Concept of School Literacy Movement Through Reading Time at SDIT Raudaturrahmah Pekanbaru
}

\author{
Erwinsah $^{1}$, Mutsyuhito Solin², Abdurrahman Adisaputera ${ }^{2}$ \\ ${ }^{1}$ Master of student in State University of Medan (UNIMED), Indonesia \\ ${ }^{2}$ State University of Medan (UNIMED), Indonesia \\ eshanerwin@gmail.com
}

\begin{abstract}
Reading time is a practice carried out by the school to support the literacy movement in Pekanbaru's Raudaturrahmah SDIT school, the program is held on Friday after Friday prayers, students are provided with 30 minutes of reading any books in school, and students bring books from home, and each week students have to report to the class teacher the results of the books they read, and at the end of each semester the class teacher reports to the school head as a result of reading time. The aim of this research is to analyze GLS activity and program in SDIT Raudaturrahmah Pekanbaru. This research used a qualitative descriptive study, namely research that intends to understand the phenomenon experienced by research subjects holistically by describing it in the form of words in a specific natural context and by utilizing various natural methods as well. The result is The GLS concept applied by SDIT Raudaturrahmah Pekanbaru is at the stage of developing GLS, and has a special GLS program that is reading time which is held every Friday with a time allocation of 30 minutes.
\end{abstract}

Keywords : Literacy culture; Reading time; Movement reading time.

\section{Introduction}

The low literacy culture of Indonesian society is a national problem that must be addressed and resolved immediately. Yuliyati (2014: 117) said that various programs had been developed by the Government, to improve the literacy culture, for example grand library blocks, School Operational Assistance (BOS), Indonesia reading, May-national book month, September month fond of reading library days (Oemar , 2009), block grand library and BOS book, Yuliyati (2014: 117) Another program is training in active, creative, effective, and fun learning (PAKEM) which emphasizes structuring the environment that is rich in writing and class libraries, school library development programs by the provincial library and regional library, mobile library, real literacy information movement, including 12 Community Reading Parks (TBM) and reading corners, 1 creative house, 1 school library in 6 cities in Indonesia, checking books, writing training, service training and management processing TBM, publishing library windows, blog writing, web, review competitions, regular discussions on TBM, activities related to violence outreach, comparative studies, sponsorship support, Indonesia reading, the selection of reading ambassadors, the establishment of library jamborees, and literacy seminars, as well as the involvement of companies in Corporate Social Responsibility (CSR) programs.

These programs show the Government's hard work in developing a written culture, but the results have not been in line with expectations. This is because there are various internal and external constraints from the teacher-student's own person as an education actor. Therefore, schools must have a systematic and systemic program that can make children read and write as much and as often as possible. Fun and competitive tips need to be developed in order to grow the hobby of reading and writing automatically without coercion. In turn, the literacy culture will grow. 
Based on this, the Ministry of Education and Culture developed the School Literacy Movement (GLS) which involved all stakeholders in the education sector, starting from the central, provincial, municipal, to educational units. In addition, the involvement of external elements and public elements, namely parents of students, alumni, society, business and industry is also an important component in GLS. GLS is developed based on nine priority agendas (Nawacita) related to the tasks and functions of the Ministry of Education and Culture, specifically Nawacita numbers 5, 6, 8, and 9. The Nawacita points are intended to (5) improve the quality of life for humans and Indonesian society; (6) increasing people's productivity and competitiveness in the international market so that the Indonesian nation can advance and rise with other Asian nations; (8) revolutionizing the nation's character; (9) strengthen diversity and strengthen Indonesia's social restoration. The low literacy culture of Indonesian society is a national problem that must be addressed and resolved immediately. Yuliyati (2014: 117) said that various programs had been developed by the Government, to improve the literacy culture, for example grand library blocks, School Operational Assistance (BOS), Indonesia reading, May-national book month, September month fond of reading library days (Oemar, 2009), block grand library and BOS book, Yuliyati (2014: 117) Another program is training in active, creative, effective, and fun learning (PAKEM) which emphasizes structuring the environment that is rich in writing and class libraries, school library development programs by the provincial library and regional library, mobile library, real literacy information movement, including 12 Community Reading Parks (TBM) and reading corners, 1 creative house, 1 school library in 6 cities in Indonesia, checking books, writing training, service training and management processing TBM, publishing library windows, blog writing, web, review competitions, regular discussions on TBM, activities related to violence outreach, comparative studies, sponsorship support, Indonesia reading, the selection of reading ambassadors, the establishment of library jamborees, and literacy seminars, as well as the involvement of companies in Corporate Social Responsibility (CSR) programs.

These programs show the Government's hard work in developing a written culture, but the results have not been in line with expectations. This is because there are various internal and external constraints from the teacher-student's own person as an education actor. Therefore, schools must have a systematic and systemic program that can make children read and write as much and as often as possible. Fun and competitive tips need to be developed in order to grow the hobby of reading and writing automatically without coercion. In turn, the literacy culture will grow.

Based on this, the Ministry of Education and Culture developed the School Literacy Movement (GLS) which involved all stakeholders in the education sector, starting from the central, provincial, municipal, to educational units. In addition, the involvement of external elements and public elements, namely parents of students, alumni, society, business and industry is also an important component in GLS. GLS is developed based on nine priority agendas (Nawacita) related to the tasks and functions of the Ministry of Education and Culture, specifically Nawacita numbers 5, 6, 8, and 9. The Nawacita points are intended to (5) improve the quality of life for humans and Indonesian society; (6) increasing people's productivity and competitiveness in the international market so that the Indonesian nation can advance and rise with other Asian nations; (8) revolutionizing the nation's character; (9) strengthen diversity and strengthen Indonesia's social restoration. 
The ability of student literacy is closely related to the demands of reading skills which lead to the ability to understand information critically, and be reflective. However, learning at school has not been able to realize this so that Pekanbaru SDIT Raudaturrahmah provides time every week which is called reading time. Therefore, the researchers conducted a study at SDR Raudaturrahmah Pekanbaru, from several research schools only SDIT Raudaturrahmah Pekanbaru which carried out the school literacy movement, and there were also public schools but no follow-up or supervision of the literacy movement carried out.

Reading time is a practice carried out by the school to support the literacy movement in Pekanbaru's Raudaturrahmah SDIT school, the program is held on Friday after Friday prayers, students are provided with 40 minutes of reading any books in school, and students bring books from home, and each week students have to report to the class teacher the results of the books they read, and at the end of each semester the class teacher reports to the school head as a result of reading time.

SDIT Raudaturrahmah Pekanbaru is an integrated SDIT school that has been and is currently carrying out school literacy movements to date. The Ministry of Education and Culture developed a school literacy movement (GLS) that involved all stakeholders in the education sector, starting from the central, provincial, district, city, to education units. The literacy movement in order to develop students' character through acculturation of the school literacy movement embodied in the school literacy movement so that they become lifelong learners.

\subsection{Literacy}

\section{Literature Review}

The definition of literacy has traditionally been expanded among different literations to include other aspects of life such as the skills to use language, numbers, images, and other ways to understand and use a system of dominant symbols of culture. The meaning of literacy continues to evolve, even now more widespread and complex. The object of literacy study empties into meaningful social divisions. The definition of past literacy which is limited to reading and writing activities is less glimpsed. The definition of contemporary literacy can be seen based on several opinions, one of which is delivered by Thomson and De Bortoli (2013: 7) that:

Literacy is developed through the specific language, enabling students to understand how the English language works in different social contexts and critically assessing writers' opinions, biases and intentions, and assisting them to make sophisticated language choices in their own texts.

That is, literacy is the development of specialized language studies in all forms, enabling students to understand how language works in different social contexts and critically assessing opinion writing, guesswork, and meaning, and helping students to make increasingly sophisticated language choices in the text they produce themselves.

\subsection{School Literacy Movement (GLS) Policy}

GLS is an overall effort to make schools as learning organizations whose citizens are literate throughout life through public involvement. Based on the guidebook made by the Ministry of Education and Culture regarding this policy, GLS has:

\section{a. Philosophical foundation}


The youth oath of the third point (3) states, "upholding the language of the Indonesian language which has the meaning of acknowledging the existence of hundreds of regional languages that have the right to live and the opportunity to use foreign languages according to their needs."

1) This item confirms the importance of language learning in national education.

2) The UN Convention on the Rights of the Child in 1989 concerning the importance of using mother tongue. Indonesia, which has a variety of ethnic groups, especially certain microcultures, needs to be facilitated with mother tongue when they enter low-grade basic education (class I, II, III).

3) The UN Convention in Prague in 2003 concerning basic literacy skills and effective library skills is the key for a literate community in the face of the rapid flow of information technology. The five essential components of information literacy are basic literacy, library literacy, media literacy, technology literacy, and visual literacy.

\section{b. Legal Foundation}

The legal foundation of the School Literacy Movement contained in the GLS master design is:

1) Article 31 Paragraph 2 of the 1945 Constitution:

"The government seeks and organizes a national education system that enhances faith and piety and noble character in order to educate the nation's life, which is regulated by Law."

2) Law of the Republic of Indonesia Number 20 of 2003 concerning the National Education System.

3) Law of the Republic of Indonesia Number 43 of 2007 concerning the Library.

4) Law of the Republic of Indonesia Number 24 of 2009 concerning Flags, Languages, and National Symbols and National Songs.

5) Government Regulation of the Republic of Indonesia Number 32 of 2013 concerning the Second Amendment to Republic of Indonesia Government Regulation Number 19 of 2005 concerning National Education Standards.

6) Government Regulation Number 24 of 2014 concerning the Implementation of Law Number 43 of 2007 concerning the Library.

\subsection{Principles of School Literacy}

According to Beers (2009), good practice in the school literacy movement emphasizes the following principles:

a. The development of literacy goes according to the predictable stage of development.

The stage of children's development in learning to read and write intertwined with each other the stages of development. Understanding the developmental stages of literacy of students can help schools to choose habituation strategies and literacy learning that are appropriate for their developmental needs.

b. A good literacy program is balanced.

Schools that implement balanced literacy programs realize that each student has different needs. Therefore, the reading strategy and type of text that is read need to be varied and adjusted to the level of education. A meaningful literacy program 
can be done by utilizing reading materials rich in various texts, such as literature for children and adolescents.

c. Literacy programs are integrated with the curriculum.

Habit and literacy learning at school is the responsibility of all teachers in all subjects because learning in any subject requires language, especially reading and writing. Thus, the professional development of teachers in terms of literacy needs to be given to teachers in all subjects.

d. Reading and writing activities are carried out at any time.

For example by writing a letter to the president or reading to the mother are examples of meaningful literacy activities.

e. Literacy activities develop oral culture.

Strong literacy-based class is expected to bring up various oral activities in the form of discussions about books during learning in class. This discussion activity also needs to open up the possibility for differences of opinion to convey their feelings and opinions, listen to each other, and respect different views.

f. Literacy activities need to develop awareness of diversity.

School residents need to appreciate the difference through literacy activities at school. Reading materials for students need to reflect the richness of Indonesian culture so that they can be exposed to multicultural experiences.

\section{Methodology}

This research is a qualitative descriptive study, namely research that intends to understand the phenomenon experienced by research subjects holistically by describing it in the form of words in a specific natural context and by utilizing various natural methods as well.

Moleong (2010: 5) states that qualitative research is research that uses natural settings, with the intention of interpreting phenomena that occur and are carried out by involving various methods. With a variety of distinctive characteristics possessed, qualitative research is unique in that it differs from quantitative research so that it can be said that this research produces analytical procedures that do not use statistical analysis procedures or other quantification methods. Bogdan and Biklen (1992: 21-22) explain that qualitative research is one of the research procedures carried out naturally and produces descriptive data in the form of words and images of the behavior of the people observed so that they do not emphasize the numbers.

Thus the research describes the School Literacy Movement at SDIT Raudaturrahmah Pekanbaru. From the results of these studies, data will be obtained regarding the implementation of the School Literacy Movement in Pekanbaru's Raudaturrahmah Integrated Islamic Primary School. From the various opinions above, it can be concluded that the qualitative approach is a research process to investigate a social phenomenon and human problems descriptively in the form of narratives arranged inductively based on natural facts in the field, because qualitative research focuses on processes rather than the results obtained by researchers when in the field.

This research was conducted at one of the elementary schools located in the southern part of the city of Pekanbaru. As a private school that has the ability to make improvements and innovations in the development of educational services and create reliable output, there 
have been many ways done by SDIT in realizing a generation of high intellectuals to face the challenges of the times and generations who have noble character towards God, others humans, and the environment.

Through preliminary observations, it was found that the teachers at SDIT Raudaturrahmah Pekanbaru had different educational backgrounds, some of them were from educational study programs and some were non-educational study programs, but they already had certificates so that the teachers could teach and get educator certification. Based on the results of interviews with the principal of SDIT Raudaturrahmah Pekanbaru, information was obtained that the total number of students was 400 students in grades 1-6, each class had 2 classes so the number of classes or study rows was 12 classes, and each class numbered 3235 students in the class. All students enrolled are graduates from Kindergarten (TK), and most students of SDIT Raudaturrahmah Pekanbaru are students of TK Raudaturrahmah Pekanbaru also because the foundation provides kindergarten, and SDIT education.

Qualitative research does not use the term population, but by Spradley in Pohan, et al (2017: 322) it is called "Social Situation" or a social situation consisting of three elements, namely: Place, Actors, and Activity which interact synergistically. The social situation can be expressed as the object of research that wants to be understood in more depth "What happens" in it. Pohan (2017: 322), qualitative research does not use population because qualitative research departs from certain cases that exist in certain social situations and the results of the study will not be applied to the population, but transferred to other places in social situations that have similarities with social situations in the case learned.

Data sources in conducting research were obtained from research subjects. According to Lincoln and Guba (1985: 201), the subjects of the study were case studies in the form of human (non-human) and non-human (events, documents and situations) observed or respondents who could be interviewed. Deeper, Lincoln and Guba (1985: 201) explain the reasons for the diverse subjects in the case study research adjusted to what data is needed, so that the selection of subjects is with a specific purpose. Similarly, Arikunto (2010: 172) identifies three sources of data into 3p, namely: person (person), stationary and / or mobile; data in the form of letters (paper).

The subjects in this study were selected based on research questions as a description of what data is needed by researchers. The data in this study are the concepts, dimensions, and impact of literacy applied by the school through the reading time program at SDIT Raudaturrahmah Pekanbaru. The object of the research was the concept of the school literacy movement that took place at SDIT Raudaturrahmah Pekanbaru, the dimensions of the literacy movement, and the impact of the school literacy movement on student learning activities to obtain data on student school literacy movements at SDIT Raudaturrahmah Pekanbaru.

\section{Discussion}

Pekanbaru's Raudaturrahmah SDIT makes a policy that can be categorized as GLS, which is reading time. This is because reading time has the same activity objectives as GLS goals, even reading time meets the stages of GLS implementation. The stages of implementing GLS in SD according to the Ministry of Education and Culture (2016: 3), namely: (1) the stage of habituation, namely the growth of interest in reading through 15minute reading activities; (2) the development stage, namely increasing literacy skills through activities to respond to enrichment books; and (3) the learning stage which is to improve literacy skills in all subjects, using enrichment books, and reading strategies in all subjects. 
The following are the results of interviews with the Principal regarding GLS policy and the purpose of reading time, "I know about the School Literacy Movement (GLS) program delivered by the Minister of Education for viewing on internet and print media. But I and this school have never received an invitation letter to attend the School Literacy Movement training. The School Literacy Movement is a reading movement, where it is hoped that our people like to read in what I am. The program is very good, but the implementation downward has not been fully fulfilled so we have never attended training about the program. Our school implements two programs, namely reading time every Friday, and PILAR every morning. GLS programmed by the government programmatically was not implemented because there was no socialization or training, but it had been implemented in advance to foster students' interest in reading. "

The opinion of the principal is also in accordance with the teacher's opinion obtained from the results of the interview, as follows: According to AY "the activities of the School Literacy Movement in this school are reading time (reading time). Long before leaving the School Literacy Movement policy, reading time had already been implemented in this school ". According to DS "this reading time when I started teaching at school already existed. Looks like a school program, probably a long time ago before the School Literacy Movement ". YS's opinion "since the establishment of this school". Opinion DA "the name of the activity of the School Literacy Movement that is applied is reading time. Maybe it's been a long time, sir, since I have been teaching here, a reading time activity has been carried out.

From the teacher's opinion above, it was concluded that the concept of the School Literacy Movement carried out in Pekanbaru's Raudhaturrahmah SDIT was in the form of reading time. Reading time has been implemented for a long time, even before leaving the School Literacy Movement policy. This is in line with the results of interviews with the Principal stating that "Reading time or time to read, means that the school provides a special time for students to read. Reading time has been implemented since this school was established, the beginning of the idea of reading time began with the low results of student examinations, the reason students are lazy to read questions ".

Furthermore, the results of the interview regarding the implementation of reading time at SDIT Raudhaturrahmah Pekanbaru in accordance with GLS stages, namely habituation, development, and learning:

According to the Principal "The reading time is held on Friday after Friday prayers every week. Previously we carried out Saturday morning after morning gymnastics, because Saturday was a holiday, we moved it on Friday. Reading time is held in the prayer room, all students gather in the prayer room according to their respective classes, each class is divided into two groups, then after completion students report the title of the reading book, what page is the book read. We have provided books in the library, but most students bring books from home according to their wishes. "

The concept of the School Literacy Movement (GLS) at Pekanbaru's Raudaturrahmah SDIT was analyzed based on four discussions, namely: (1) policy decisions; (2) GLS implemented by schools; (3) time allocation used; and (4) Dissemination of the GLS concept. Data on the concept of the School Literacy Movement based on special policy decisions was obtained from interviews with the Principal who stated that "I know about the School Literacy Movement (GLS) program delivered by the Minister of Education for viewing on internet media and print media. But I and this school have never received an invitation letter to attend the School Literacy Movement training. The School Literacy Movement is a reading 
movement, where it is hoped that our people like to read in what I am. The program is very good, but the implementation downward has not been fully fulfilled so we have never attended training about the program. Our school implements two programs, namely reading time every Friday, and PILAR every morning. GLS programmed by the government is not programmed because there has been no socialization or training, but in purpose it has been implemented in advance to foster students' interest in reading. "

The GLS concept carried out by Pekanbaru's Raudhaturrahmah SDIT is in the form of reading time. Reading time has been implemented since the school was established, namely before the School Literacy Movement policy was released. The time allocation used for reading time is 30 minutes to be exact every Friday at 13.30-14.00. The reading time is held at the mosque, and specifically for students who cannot read will be trained face to face.

GLS socialization carried out by SDIT Raudhaturrahmah Pekanbaru consisted of two statements, namely: socialization to student guardians about reading time and socialization to teachers regarding the School Literacy Movement. Socialization to student guardians about reading time has been done in various ways, there are teachers who directly deliver the program, there are guardians of students who know from the lesson roster, and there are those who know from children because their children ask to be brought books besides textbooks every Friday. While the socialization of the School Literacy Movement which is a government policy has never been given to teachers or principals, even teachers have never heard of it and the principal knows it from internet media and print media. But the purpose and real form of the School Literacy Movement has been carried out by this school, even becoming a school program for a long time, namely reading time on Fridays and PILAR every morning.

USAID (2014: 2) states that literacy is a person's language skills (listening, speaking, reading, and writing) to communicate in different ways according to his purpose. This opinion of Resmini in Fuad (2015: 105) states that literacy is broadly interpreted as a language ability that includes the ability to listen, speak, read, and write, and the ability to think that is an element in it. The same thing expressed by Fuad (2015: 2) suggested that literacy is the ability to read and write in carrying out tasks related to the world of work and life outside of school. Taking into account the various opinions that have been reviewed, it can be emphasized that literacy is development in all forms that enable students to understand how language works in different social contexts and critically assess the writing of opinions, expectations, and meanings, and help students to make language choices the more sophisticated the text they produce themselves, so that it becomes a social and cultural sensitive person.

GLS is an overall effort to make schools as learning organizations whose citizens are literate throughout life through public involvement. In order for schools to be able to become the front line in the development of literacy culture, Beers et al. In the book A Principal's Guide to Literacy Instruction in Wiedarti Pengesti (2016: 12) convey several strategies to create a positive literacy culture in schools, namely: (1) condition literacy friendly physical environment; (2) striving for a social and affective environment as a literate model of communication and interaction; and (3) strive for school as a literate academic environment. While the stages of the School Literacy Movement according to the book The Master Design of School Literacy Movement (2016), namely: habituation, development, and learning. The main stage is habituation because this stage fosters a culture of literacy in children. Even at SDIT Raudaturrahmah Pekanbaru has applied the stages of literacy habituation for a long 
time, even before the policy on GLS was issued. The habituation stages are listed in a school program or learning activity called reading time.

The results of previous studies that have been published in national and international journals include, namely: Eko Nurdiyanti and Edy Suryanto (2010: 115). LITERA Journal. Research with the title "Indonesian Language Literacy Learning in Class V Elementary School Students". Next is a study entitled What Is Literacy? The Power of a Definition was written and published in the journal Research \& Practice for Persons with Severe Disabilities University of New Mexico by Elizabeth B. Keefe and Susan R. Copeland (2011: 92) discussing reading, literacy, moderate / severe disability, definition of literacy . According to Kliewer, Biklen, and Kasa-Hendrickson (2006) in Elizabeth B. Keefe and Susan R. Copeland (2011: 92) concluded that much of the history of literacy for people who need broad support has been characterized by pessimistic narratives (p. 175). Jane Waldfogel (2012: 40) in a study entitled The Role of Out-of-School Factors in Literacy Problems conducting an implementation analysis examining factors outside of school can contribute to literacy gaps in schools and to widening the gap between groups later. Some important factors in the group. For example, differences in parenting assistance explain black-and-white literacy gaps and gaps related to socio-economic status. Other factors differ from groups. For example, the main influence on early literacy for immigrant children is the language used at home, parental abilities in English, and whether a child participates in preschool.

Based on the results of interviews with principals and teachers, it was concluded that reading time activities were an example of GLS implementation that had been implemented by SDIT Raudaturrahmah Pekanbaru for a long time. However, reading time activities only cover part of the GLS development stage, because there are still some elements from this stage that have not been fulfilled, aka the process is still being developed.

The stages of implementing GLS in SD according to the Ministry of Education and Culture (2016: 3), namely: (1) the stage of habituation, namely the growth of interest in reading through 15-minute reading activities; (2) the development stage, namely increasing literacy skills through activities to respond to enrichment books; and (3) the learning stage which is to improve literacy skills in all subjects, using enrichment books, and reading strategies in all subjects. In detail, the stages of GLS habituation that were applied to the reading time at Raudaturrahmah Pekanbaru Elementary School, namely: having special activities for reading 15 minutes even in this school have allocated a special time of reading for 30 minutes even if only on Fridays, at the school there is a library and process making a classroom reading area or corner, and the last is public involvement (parents or guardians of students) in reading time activities so that parents can support children by buying books and also getting children to read at home.

The stages of GLS development were applied to the reading time at Raudaturrahmah Pekanbaru Elementary School, namely: varied reading strategies starting from reading inwardly independently to interactive reading aloud, then students making notes or reports after reading and specifically at high school elementary schools were also asked to discuss read stories, and students also use the class library but for reading areas or angles it is still in the manufacturing process so that it cannot be used optimally. The stages of GLS learning have not been implemented at Pekanbaru's Raudaturrahmah SDIT, because of several things including: reading time is only carried out during special hours and reading activities for learning are only carried out by class I and class IV students applying the 2013 curriculum, students are not required to produce a related work with books that are read, then the library 
and reading corner of the class are used only when the reading time activities take place not on each lesson.

The results of the interview are in accordance with the results of observations that 7 of the 10 indicators in the GLS habituation stage have been applied at SDIT Raudaturrahmah Pekanbaru through the reading time program. The 7 indicators are met, namely: (1) there are 15 minutes of reading activities; (2) the book that is read is then recorded the title and author; (3) teachers and principals participate in 15-minute reading activities; (4) there is a school library or room for storing non-lesson books; (5) there is a class reading corner; (6) there is text rich material in each class; and (7) the school seeks to involve the public to develop school literacy activities. Because more indicators were met than those that were not, it was concluded that the GLS habituation stage through the reading time program at Pekanbaru Raudaturrahmah SDIT had been carried out so that the next stage could be measured, namely the development of GLS.

From the observations it was found that 4 of the 6 indicators in the GLS development stage had been implemented at SDIT Raudaturrahmah Pekanbaru through the reading time program. The 4 indicators are met, namely: (1) there are 15 minutes of reading activities; (2) there are activities to respond to enrichment books during literacy lessons or hours of activities in the library / reading corner or relevant lesson hours; (3) there are activities to respond to reading through interactive reading activities, integrated reading, reading together, and reading independently; and (4) there are activities to appreciate students' literacy achievements. Because more indicators are fulfilled than those that are not, it is concluded that the GLS development stage through the reading time program at SDIT Raudaturrahmah Pekanbaru has been implemented but has not been perfect, even from observational notes also found several things that are still in the process of forming and developing literacy so that it can be measured the next stage is GLS learning.

From the observations it was found that only 1 of the 6 indicators in the GLS learning phase had been implemented at SDIT Raudaturrahmah Pekanbaru through the reading time program. The 1 indicator is fulfilled, namely: there are activities to respond to reading in the form of oral, written, artistic, craft, etc., in accordance with the literacy skills of students. Due to only 1 indicator being fulfilled, it was concluded that the GLS learning phase through the reading time program at SDIT Raudaturrahmah Pekanbaru had not been implemented.

From the description of the results of the interviews and the results of these observations, it can be concluded that the GLS concept applied by SDIT Raudaturrahmah Pekanbaru is at the stage of developing GLS, and has a special GLS program that is reading time which is held every Friday with 30 minutes of time allocation.

\section{Conclusion}

The GLS concept applied by SDIT Raudaturrahmah Pekanbaru is at the stage of developing GLS, and has a special GLS program that is reading time which is held every Friday with a time allocation of 30 minutes. Reading time has been implemented since the school was established, namely before the School Literacy Movement policy was released. The time allocation used for reading time is 30 minutes to be exact every Friday at 13.3014.00. The reading time is held at the mosque, and specifically for students who cannot read will be trained face to face. Socialization to student guardians about reading time has been done in various ways, there are teachers who directly deliver the program, there are guardians 
of students who know from the lesson roster, and there are those who know from children because their children ask to be brought books besides textbooks every Friday. While the socialization of the School Literacy Movement which is a government policy has never been given to teachers or principals, even teachers have never heard of it and the principal knows it from internet media and print media. But the purpose and real form of the School Literacy Movement has been carried out by this school, even becoming a school program for a long time, namely reading time on Fridays and PILAR every morning.

\section{References}

Arikunto, S. 2010. Prosedur Penelitian Suatu Pendekatan Praktik. Jakarta: Rineka Cipta. Ali, M. 2011. Memahami Riset Prilaku dan Sosial. Bandung: Pustaka Cendekia Utama.

Beers, C.S., Beers, J. W., \& Smith, J,O. 2009. A Principal's Guide to Literacy Instruction. New York: Guilford Press.

Bogdan, R. \& Biklen, S. 1992. Qualitatif Research for Education. Boston, MA: Allyn and Bacon.

Binkley, Marilyn dan Williams, Trevor. 1996. Reading Literacy in the United States: Findings From the IEA Reading Literacy Study. Washington: Government Printing Office.

Bearne, Dombaey, Grainger. 2003. Clasroom Interaction in Literacy. Library of Congress Cataloging-in-Publication Data CIP data has been applied for.

Creswell, J. W. 2010. Research Design Pendekatan Kualitatif, Kuantitatif, dan Mixed. Yogyakarta: Pustaka Pelajar.

Faizah, D.U., dkk. 2016. Panduan Gerakan Literasi Sekolah di Sekolah Dasar. Jakarta: Direktorat Jenderal Pendidikan Dasar dan Menengah Kementerian Pendidikan dan Kebudayaan.

Fuad, Zaki Al. 2015. Pemanfaatan Literasi dalam Pembelajaran Bahasa Indonesia di Sekolah Dasar. Dalam Ernawulan Syaodih, at.all(Ed). Membangun Imajinasi dan Kreativitas Anak Melalui Literasi. Sekolah Pascasarjana Program Studi Pendidikan Dasar Universitas Pendidikan Indonesia. Bandung. 103-110.

Kemendikbud. 2016. Panduan Gerakan Literasi Sekolah di Sekolah Dasar. Jakarta: Direktorat Jenderal Pendidikan Dasar dan Menengah Kementerian Pendidikan dan Kebudayaan.

Kucer. B Stephen. 2009. Dimensions of Literacy, A conceptual Base for Teaching Reading and Writing in Scool Setting. In the Taylor \& Francis e-Library.

Leonhardt, Mary. 2001. 99 Cara menjadikan Anak Anda "Kerajinan Membaca. Terjemahan oleh Alwiyah Abdurrahman. 2001. Bandung: Kaifa.

Lincoln, Y. S., \& Guba, E. G. 1985. Naturalistic Inquiry. California: Sage Publications.

Moleong, L. 2010. Metodologi Penelitian Kualitatif(edisi revisi). Bandung: Remaja Rosdakarya.

Miles, M. B., \& Huberman, A. M. 1994. Qualitative Data Analysis: an expanded sourcebook. London: Sage Publications.

Wiedarti Pangesti, dkk. 2016. Desain Induk Gerakan Literasi Sekolah. Jakarta: Direktorat Jendral Pendidikan Dasar dan Menengah Kementrian Pendidikan dan Menengah.

Sugiyono. 2013. Memahami Penelitian Kualitatif. Bandung: Alfabeta.

Trianto. 2010. Pengantar Penelitian Pendidikan bagi Pengembangan Profesi Pendidikan \& Tenaga Kependidikan. Jakarta: Kencana. 
Thomson, Sue, dan De Bortoli. 2012. Preparing Australian Students for the Digital Word: Results from the PISA 2009 Digital Reading Literacy Assesment. Victoria (Australia): ACER Press.

Thomson, Sue, Hillman, Kylle, dan De Bortoli, Lisa Jean. 2013. A Teacher's Guide to PISA Reading Literacy. Victoria (Australia): ACER Press.

UNESCO. 2005. Literacy for Life. Paris (Prancis): United Nations Educational, Scientific, and Cultural Organization.

UNESCO. 2014. Teaching and Learning: Achhieving Quality for All. Paris (Prancis): United Nations Educational, Scientific, and Cultural Organization.

USAID. 2014. Buku Sumber untuk DOSEN LPTK: Pembelajaran Literasi Kelas Awal di LPTK. Jakarta: USAID PRIORITAS.

Widodo, Slamet, dkk. 2015. Membangun Kelas Literat Berbasis Pendidikan Lingkungan Hidup Untuk Melatihkan Kemampuan Literasi Siswa Di Sekolah Dasar. Peningkatan Kualitas Peserta didik Melalui Implementasi Pembelajaran Abad 21. Fakultas Keguruan dan Ilmu Pendidikan Universitas Muhammadiyah Sidoarjo. 60-73.

Wiedarti. 2016. Desain Induk Gerakan Literasi Sekolah.direktorat Jendral Pendidikan dasar dan Menengah Kementrian Pendidikan dan Kebudayaan.

Andina, Elga. 2017. PentingnyaLiterasiBagiPeningkatanKualitasPemuda. Majalah Info SingkatKesejahteraanSosial, Vol. IX, No.21, Puslit, November 2017, page. 9-12.

Baleiro, Rita. 2011. A Definitioan of Literacy: A content Analysis of Literacy of Literatur Syllabuses and interviews with portuguese Lecturers of Literature. Journal of New Horizons in education, (online), Volume 1, Issue 4, (http:www.tojned.net//pdf/tojnedv01i04-02.pdf), diakses tanggal 22 Mei 2017. Page. 16-25.

Dressler, C., \&Kamil, M. (2006).First- and second-language literacy. In D. August \& T. Shanahan (Eds.), Developing literacy in second language learners: Report of the National Literacy Panel onLanguage-Minority Children and Youth (pp. 197-238). Mahwah,NJ: Erlbaum.

Gaske, Andrejs dan Ozola, Antra. 2008. Factors Influencing Reading Literacy at The Primary School Level. Journal Problems of Education in the 21st Century, (online) Vol. 6, (http://jbse.webinfo).Geske.Pdf, accessed on May 22 ${ }^{\text {nd }}, 2017$ ). Page.71-77.

Genesee, F., Geva, E., Dressler, C., \& Kamil, M. (2006). Synthesis : Cross-linguistic relationships. In D. August \& T. Shanahan (Eds.), Developing literacy in secondlanguage learners: Report of the National Literacy Panel on Language-Minority Children and Youth(pp. 153-183). Mahwah, NJ: Erlbaum

Gipayana Muhammad. 2004. "Pengajaran Literasi dan Penilaian Portofolio dalam konteks Pembelajaran Menulis di SD”, in Jurnal Ilmu Pendidikan. Februari 2004, volume 11, Number 1, Page.59-70.

Goldenberg, C. (2010). Reading instruction for English language learners. In M. Kamil, P. D. Pearson, E. Moje, \& P. Afflerbach (Eds.). Handbook of Reading Research, Vol. IV (pp. 684-710). Newark, DE: International Reading Association.

Jane Waldfogel. 2012. The Role of Out-of-School Factors in the Literacy Problem. THE FUTURE OF CHILDREN. VOL. 22 / NO. 2. Page 40-54.

Keefe, Elizabeth B. Keefe, Susan R. Copeland. 2011. What Is Literacy? The Power of a Definition. Research \& Practice for Persons with Severe Disabilities 2011, Vol. 36, No. 3Y4, Page 92-99. 
Nurdiyanti Eko, Suryanto Edy. 2010. Pembelajaran Literasi Mata Pelajaran Bahasa Indonesia Pada Siswa Kelas V Sekolah Dasar. Jurnal PAEDAGOGIA, volume 13, Number 2, pp.115-128.

Pohan Rahmadanni, Fitrianti Leni, Siregar Hidayah Robiatul. 2017. Program Mushafahah (Bersalaman) Sebagai Upaya Character Building Pada Siswa Sekolah Dasar Islam Swasta Pekanbaru. Jurnal PIGUR, Volume 03, Number 01, pp. 315-325.

PIRLS. 2015.PIRLS 2016 Assessment Framework:2nd Edition. Boston (USA): TIMSS \& PIRLS Internasional Study Center, Lynch School of Education, Boston College, and Internasional Association for the Evaluation of Education Achievement (IEA).

Stephen B. Kucher, 2015. Literacy: Varied, Dynamic, and Multidimensional. Journal of Family Strenghts, Vol. 15, Issue.2, Article 1, 2015. pp: 1-35.

Suryaman Maman. 2015. Analisis Hasil Belajar Peserta Didik dalam Literasi Membaca Melalui Studi Internasional (Pirls) 2011.Jurnal LITERA, Vol. 14, No. 1, pp. 170-186.

Wahyuni Sri. 2010. Menumbuhkembangkan Minat Baca Menuju Masyarakat Literat. diksi Vol 17 No. 1, pp. 179-189.

Wandasari, Yulisa. 2017.Implementasi Gerakan Literasi Sekolah (GLS) sebagai Pembentuk Pendidikan Karakter. Jurnal Manajemen, Kepemimpinan, danSupervisiPendidikan, Vol. 1, No.1, Juli-Desember 2017, pp. 325-342.

Yuliyati. 2014. Model Budaya Baca-Tulis Berbasis Balance Literacy dan Gerakan Informasi Literasi di SD. Jurnal Ilmu Pendidikan, vol. 20, No.1, pp.117-126.

Fendrik Muhammad. 2014. Analisis kemampuan koneksi matematis dan habits of mind siswa kelas $v$ sekolah dasar. pp. 45.

Peraturan mentri pendidikan dan kebudayaan No. 23 in 2015 about Penumbuhan Budi Pekerti.

Peraturan mentri pendidikan nasional (Permendiknas) No. 22 in 2006 about Standar Kompetensi Lulusan (SKL).

Gewati Mikhael. 2016. Minat Baca Indonesia Ada di Urutan ke-60 Dunia. (Online,http://edukasi.kompas.com/read/2016/08/29/07175131/minat.baca. Indonesia.ada.iurutan.ke-60.dunia, accessed on August 27 ${ }^{\text {th }}, 2017$ ). 